\title{
PEMBELAJARAN CALISTUNG PENDIDIKAN ANAK USIA DINI DAN UJIAN MASUK CALISTUNG SEKOLAH DASAR DI BANDAR LAMPUNG
}

\author{
NUR ASIAH \\ Email: nurasiah@ radenintan.ac.id \\ DOSEN JURUSAN PGMI FAKULTAS TARBIYAH DAN KEGURUAN UIN \\ RADEN INTAN LAMPUNG
}

\begin{abstract}
Abstrak
Pembelajaran aksara menjadi bagian dalam kurikulum Pendidikan Anak Usia Dini (PAUD).Pembelajaran aksara ini pada dasarnya lebih ditujukan sebagai pengenalan keterampilan membaca, menulis dan menghitung. Hal itu sebagaimana tertuang dalam Standar Isi Tingkat Pencapaian Perkembangan Anak (STPPA) Usia 4-5 dan 5-6 Tahun lampiran I peraturan menteri (Permen) pendidikan dan kebudayaan Republik Indonesia nomor 137 tahun 2014. Pengenalan ini diberikan dengan maksud untuk mempersiapkan kelak anak untuk masuk jenjang pendidikan selanjutnya, yakni pendidikan dasar.

Namun demikian, model pembelajaran ideal Calistung PAUD semacam itu menyisakan permasalahan serius dilihat dalam konteks yang lebih luas.Khususnya apabila dikaitkan dengan kesempatan untuk melanjutkan jenjang pendidikan dasar (SD/MI).Beberapa tahun belakangan, masyarakat diresahkan dengan adanya ujian masuk SD/ MI yang berupa tes Calistung.Tidak sedikit SD/ MI menerapkan ujian masuk Calistung sebagai syarat penerimaan siswa baru dengan standar yang dibuat oleh masing-masing SD/ MI.

Jenis Penelitian ini adalah penelitian kualitatif dengan sumber data sekolah TK dan SD yang Ada di Bandar Lampung.Pendekatan yang digunaka dalam penelitian ini adal pendekatan naturalistic. Teknik pengumpulan data yang digunakan observasi, wawancara dan dokumentasi difokuskan untuk mengenali dan menggali permasalahan di balik penerapan semua fenomena tersebut, yakni pembelajaran Calistung di TK/ RA dan penerapan Ujian Calistung sebagai persyaratan masuk Sekolah Dasar. Masih maraknya praktik ini tidak boleh hanya dilihat sebagai praktik ketidaksadaran/ guru TK/RA akan konsep, hakikat dan batasan Pendidikan Anak Usia Dini. Tidak boleh dilihat hanya sebagai ketidaktaatan atau ketidakdisplinan SD/ MI terhadap Permen Nomor 17 tahun 2010 pasal 69 dan 70 yang mengatur tata cara penerimaan siswa SD/ MI.

Hasil penelitian menunjukan bahwa pembelajaran calistung pendidikan anak usia dini dan ujian masuk calistung sekolah dasar di Bandar Lampung masih menyisakan banyak pekerjaan rumah terutama bagi dinas Pendidikan dan Kebudayaan Kota Bandar Lampung yang sebagian besar baik TK/RA kurang benar dalam menerapkan pembelajaran yang seharusnya diberikan sesuai dengan
\end{abstract}


fase-fase perkembangan anak-anak. Begitu juga dengan penerapan ujian masuk calistung untuk sekolah dasar sebagian besar sekolah-sekolah masih mengadakan ujian masuk calistung walaupun secara diam-diam itupun dinilai kurang benar walaupun ujian tersebut bukan penentu lulus tidaknya calon siswa masuk kesekolah dasar.

Kata Kunci :Calistung, Sekolah Dasar, Pendidikan Anak Usia Dini, Ujian Masuk Sekolah.

\section{A. PENDAHULUAN}

Pembelajaran aksara menjadi bagian dalam kurikulum Pendidikan Anak Usia Dini (PAUD).Pembelajaran aksara ini pada dasarnya lebih ditujukan sebagai pengenalan keterampilan membaca, menulis dan menghitung. (Irene Guntur, M.Psi, CGA, 2014). Hal itu sebagaimana tertuang dalam Standar Isi Tingkat Pencapaian Perkembangan Anak (STPPA) Usia 4-5 dan 5-6 Tahun lampiran I peraturan menteri (Permen) pendidikan dan kebudayaan Republik Indonesia nomor 137 tahun 2014. Pengenalan ini diberikan dengan maksud untuk mempersiapkan kelak anak untuk masuk jenjang pendidikan selanjutnya, yakni pendidikan dasar.Berikut capaian keterampilan keaksaraan yang dimaksud dalam Permen 137 Tahun 2014:

Tabel. 1

Permen 137 Tahun 2014: 25.

\begin{tabular}{|c|c|c|}
\hline \multirow{2}{*}{$\begin{array}{c}\text { Lingkup } \\
\text { Perkembangan }\end{array}$} & \multicolumn{2}{|c|}{ Tingkat Pencapaian Perkembangan Anak } \\
\hline & Usia $4-5$ tahun & Usia $5-6$ tahun \\
\hline B. Berfikir Logis & $\begin{array}{l}\text { 1. Mengklasifikasikan benda } \\
\text { berdasarkan fungsi, bentuk atau } \\
\text { warna atau ukuran } \\
\text { 2. Mengenal gejala sebab-akibat yang } \\
\text { terkait dengan dirinya } \\
\text { 3. Mengklasifikasikan benda ke dalam } \\
\text { kelompok yang sama atau kelompok } \\
\text { yang sejenis atau kelompok yang } \\
\text { berpasangan dengan } 2 \text { variasi } \\
\text { 4. Mengenal pola (misal, AB-AB dan } \\
\text { ABC-ABC) dan mengulanginya } \\
\text { 5. Mengurutkan benda berdasarkan } 5 \\
\text { seriasi ukuran atau warna }\end{array}$ & $\begin{array}{l}\text { 1. Mengenal perbedaan berdasarkan ukuran: } \\
\text { "lebih dari"; "kurang dari"; dan "paling/ter" } \\
\text { 2. Menunjukkan inisiatif dalam memilih tema } \\
\text { permainan (seperti: "ayo kita bermain } \\
\text { pura-pura seperti burung") } \\
\text { 3. Menyusun perencanaan kegiatan yang akan } \\
\text { dilakukan } \\
\text { 4. Mengenal sebab-akibat tentang } \\
\text { lingkungannya (angin bertiupmenyebabkan } \\
\text { daun bergerak, air dapat menyebabkan } \\
\text { sesuatu menjadi basah) } \\
\text { 5. Mengklasifikasikan benda berdasarkan } \\
\text { warna, bentuk, dan ukuran ( } 3 \text { variasi) } \\
\text { 6. Mengklasifikasikan benda yang lebih } \\
\text { banyak ke dalam kelompok yang sama atau } \\
\text { kelompok yang sejenis, atau kelompok } \\
\text { berpasangan yang lebih dari } 2 \text { variasi } \\
\text { 7. Mengenal pola ABCD-ABCD } \\
\text { 8. Mengurutkan benda berdasarkan ukuran } \\
\text { dari paling kecil ke paling besar atau } \\
\text { sebaliknya }\end{array}$ \\
\hline
\end{tabular}


Tabel. 2

Permen 137 Tahun 2014: 26.

\begin{tabular}{|c|c|c|}
\hline \multirow{2}{*}{$\begin{array}{c}\text { Lingkup } \\
\text { Perkembangan }\end{array}$} & \multicolumn{2}{|c|}{ Tingkat Pencapaian Perkembangan Anak } \\
\hline & Usia $4-5$ tahun & Usia $5-6$ tahun \\
\hline C. Berfikir Simbolik & $\begin{array}{l}\text { 1. Membilang banyak benda satu sampai } \\
\text { sepuluh } \\
\text { 2. Mengenal konsep bilangan } \\
\text { 3. Mengenal lambang bilangan } \\
\text { 4. Mengenal lambang huruf }\end{array}$ & $\begin{array}{l}\text { 1. Menyebutkan lambang bilangan } 1-10 \\
\text { 2. Menggunakan lambang bilangan untuk } \\
\text { menghitung } \\
\text { 3. Mencocokkan bilangan dengan lambang } \\
\text { bilangan } \\
\text { 4. Mengenal berbagai macam lambang huruf } \\
\text { vokal dan konsonan } \\
\text { 5. Merepresentasikan berbagai macam benda } \\
\text { dalam bentuk gambar atau tulisan (ada } \\
\text { benda pensil yang diikuti tulisan dan } \\
\text { gambar pensil) }\end{array}$ \\
\hline $\begin{array}{l}\text { II. Bahasa } \\
\text { A. Memahami } \\
\text { bahasa }\end{array}$ & $\begin{array}{l}\text { 1. Menyimak perkataan orang lain } \\
\text { (bahasa ibu atau bahasa lainnya) } \\
\text { 2. Mengerti dua perintah yang diberikan } \\
\text { bersamaan } \\
\text { 3. Memahami cerita yang dibacakan } \\
\text { 4. Mengenal perbendaharaan kata } \\
\text { mengenai kata sifat (nakal, pelit, baik } \\
\text { hati, berani, baik, jelek, dsb) } \\
\text { 5. Mendengar dan membedakan bunyi- } \\
\text { bunyian dalam Bahasa Indonesia } \\
\text { (contoh, bunyi dan ucapan harus } \\
\text { sama) }\end{array}$ & $\begin{array}{l}\text { 1. Mengerti beberapa perintah secara } \\
\text { bersamaan } \\
\text { 2. Mengulang kalimat yang lebih kompleks } \\
\text { 3. Memahami aturan dalam suatu permainan } \\
\text { 4. Senang dan menghargai bacaan }\end{array}$ \\
\hline
\end{tabular}

Pengenalan ini menurut Maryatun idealnya dilakukan melalui 3 tahap, yakni: Tahap 1 adalah membaca gambar. Anak diberikan gambar, yang dalam satu halaman hanya memuat satu jenis gambar, misalnya jika di situ ada gambar ayam, maka gambar tidak boleh dihias dengan jenis gambar lain. Jika buku, maka buku tersebut hanya berisi gambar, belum tulisan.Tahap II : membaca gambar + huruf. Keterampilan membaca anak tahap kedua ini dengan membaca huruf yang sesuai dengan huruf awal objek gambar.Contoh : huruf A untuk gambar ayam dan B untuk buku. Tahap III : membaca gambar + kata keterampilan membaca tahap selanjutnya adalah dengan memperlihatkan gambar dan tulisan makna gambar. (Ika Budi Maryatun)

Pembelajaran calistung sebagaimana dijelaskan oleh Maryatun tersebut sejalan dengan ketentuan umum dalam Permen 137 Tahun 2014 Pasal 1 ayat 13, yang menjelaskan, bahwa: "Pembelajaran adalah proses interaksi antar anak didik, antara anak didik dan pendidik dengan melibatkan orangtua serta sumber belajar pada suasana belajar dan bermain di satuan atau program PAUD." Maka pembelajaran calistung untuk PAUD lebih menekankan pada kegiatan bermain.Sejalan pula apa yang diungkap oleh Netty Herawati, Anggota Badan 
Akreditasi Nasional Kelompok Kerja (Pokja) Pendidikan Anak Usia Dini (PAUD). Ia mengatakan :

“(Calistung) Cara mengajarkannya dengan metode bermain yang menyenangkan sehingga mereka mau melakukan secara suka rela. "Misalnya anak-anak diberikan alternatif pilihan dalam belajar huruf. Kalau anak-anak kinestetik diajarkan meniru huruf dengan gerakan anggota tubuh. Anak-anak juga bisa bermain kata, misalnya diminta menyebutkan nama buah-buahan dengan awalan 'pa'." (Dyah Ratna Meta Novi. 2013)

Namun demikian, model pembelajaran ideal Calistung PAUD semacam itu menyisakan permasalahan serius dilihat dalam konteks yang lebih luas.Khususnya apabila dikaitkan dengan kesempatan untuk melanjutkan jenjang pendidikan dasar (SD/MI).Beberapa tahun belakangan, masyarakat diresahkan dengan adanya ujian masuk SD/ MI yang berupa tes Calistung. Tidak sedikit SD/ MI menerapkan ujian masuk Calistung sebagai syarat penerimaan siswa baru dengan standar yang dibuat oleh masing-masing SD/ MI. Hal ini sebagaimana yang dikelukaan oleh (Masuk SD. 2012). Yang terjadi dalam konteks ini adalah, TK/ RA dihadapkan pada standar lain di luar standar yang ditentukan oleh Permen 137 tahun 2014. Atau dengan kata lain, adanya benturan standar Calistung TK/RA dengan standar ujian masuk Calistung yang dibuat oleh SD/MI .

Permasalahan ini memunculkan kritik dari sejumlah pemerhati Anak Usia Dini. Di antaranya adalah, ketua Komisi Nasional Perlindungan Anak Indonesia (KNPAI), Seto Mulyadii (Kak Seto).Ia mengkritik pemberlakuan tes ujian Calistung untuk masuk SD/ MI, bahwa, "dunia anak-anak adalah bermain. Betulbetul bermain bergembira kompetensinya.Membaca menulis menghitung (Calistung) itu adalah kompetensi di SD. Di TK/ RA tidak dituntut itu.Di TK adalah taman bermain bergembira, bersosialisasi dan satu yang paling utama etikanya dulu." (Kak Seto. 2015)

Menteri Pendidikan di tahun 2015, Mohammad. Nuh, juga angkat bicara melihat maraknya praktik semacam ini. Ia mengeluarkan peringatan tegas kepada SD/ MI untuk tidak menerapkan ujian masuk Calistung. Sebab pemerintah melalui kementrian pendidikan telah melarang pelaksaan tes semacam itu 
sebagaimana tertuang dalam Permen 17 tahun 2010 Pasal 69 Ayat 5, yakni: "Penerimaan peserta didik kelas 1 (satu) SD /MI atau bentuk lain yang sederajat tidak didasarkan pada hasil tes kemampuan membaca, menulis, dan berhitung, atau bentuk tes lain". Sebagai gantinya penerimaan siswa baru diatur oleh pemerintah sebagaimana tertera pada Pasal 70 Ayat 1-5, yakni: (1) Dalam hal jumlah calon peserta didik melebihi daya tampung satuan pendidikan, maka pemilihan peserta didik pada SD/ MI berdasarkan pada usia calon peserta didik dengan prioritas dari yang paling tua.(2) Jika usia calon peserta didik sebagaimana dimaksud pada ayat (1) sama, maka penentuanpeserta didik didasarkan pada jarak tempat tinggal calon peserta didik yang paling dekat dengan satuan pendidikan.(3) Jika usia danlatau jarak tempat tinggal calon peserta didik dengan satuan pendidikan sebagaimana dimaksud pada ayat (1) dan ayat (2) sama, maka peserta didik yang mendaftar lebih awal diprioritaskan"

Namun demikian, hingga hari ini praktik-praktik baik pembelajaran calistung itu masih marak terjadi. Bahkan dapat dikatakan mengarah pada kondisi yang semakin problematis.Tidak sedikit saat ini sekolah justru menerapkan ujian Calistung untuk masuk TK/ RA.Toko-toko buku saat ini mulai dibanjiri bukubuku pembelajaran Calistung untuk persiapan tes masuk SD/ MI, seperti “Aku Siap Masuk SD” dan sejenisnya. Lebih jauh lagi, usia pra-sekolah pun sekarang sudah harus giat belajar menghadapi persaingan masuk TK/ RA sehingga banyak terbit buku-buku persiapan masuk TK, seperti "Sukses Masuk TK”, “99,99\% Diterima Masuk TK Favorit”, dan "Lolos Tes Masuk TK."
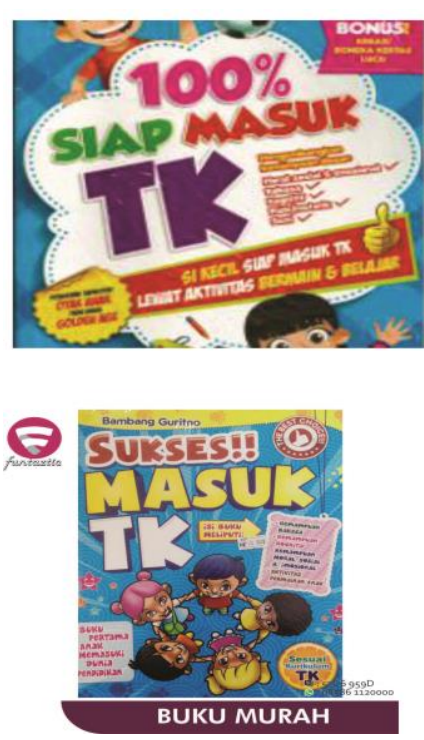
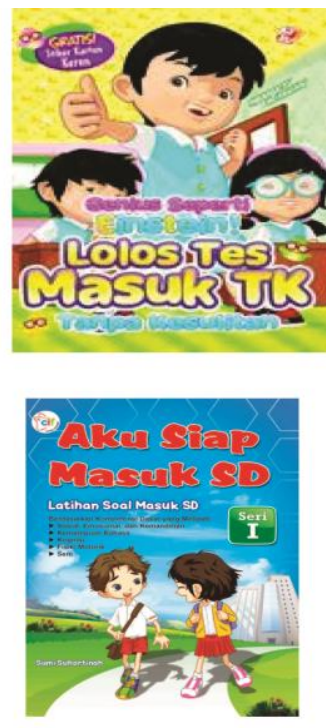
Gambar 1. buku-buku persiapan masuk SD/MI dan TK/RA

Di sisi lain, TK/RA pun tidak dapat berbuat banyak menghadapi berbagai tekanan yang berkaitan dengan itu. Selain tekanan karena ujian masuk SD/ MI semacam itu, penyelenggara TK/ RA juga mendapatkan tekanan dari orangtua.Persentase jumlah lulusan TK/ RA yang diterima masuk SD/ MI juga menjadi perhatian dan penilaian orangtua terhadap kualitas pembelajaran TK/ RA. "Semakin banyak peserta didik TK/RA yang berhasil masuk SD/ MI, maka semakin baik pula kualitasnya dinilai” demikian ungkap salah seorang narasumber penelitian ini. Untuk itu tidak sedikit - jika tidak mau dibilang rata-rata - TK/ RA yang menerapkan model pembelajaran Calistung standar masuk Sekolah Dasar agar jumlah siswa mereka tidak menurun. (Ibu Wiryati. Guru TK. 2017)

Penelitian ini difokuskan untuk mengenali dan menggali permasalahan di balik penerapan semua fenomena tersebut, yakni pembelajaran Calistung di TK/ RA dan penerapan Ujian Calistung sebagai persyaratan masuk Sekolah Dasar. Masih maraknya praktik ini tidak boleh hanya dilihat sebagai praktik yang lumrah.

Peneliti melihat, masih maraknya dan semakin meningkatnya praktikpraktik semacam itu tersebut disebabkan adanya cara pandang yang berbeda antara guru TK/RA dan SD di lapangan dengan sudut pandang pemerintah maupun pemerhati pendidikan dalam melihat fenomena ini. Perbedaan cara pandang ini menjelaskan, mengapa hingga hari ini praktik yang dimaksud masih berjalan dan bahkan semakin meningkat. Oleh sebab itu, jalan keluar untuk menyelesaikannya adalah dengan cara adovokasi dan mediasi. Yang dimaksud advokasi dalam konteks penelitian ini adalah dengan cara menyelami dan menggali logika, cara pandang, konsep-konsep,nilai-nilai serta permasalahan dan tantangan yang dimiliki dan dihadapi oleh para guru, baik TK/RA dan SD/ MI dalam proses belajar-mengajar. Sementara yang dimaksud mediasi adalah, mendudukan cara pandang yang dimiliki guru - sebagai ujung tombak pendidikan di lapangan - dengan cara pandang pemerintah dan pemerhati sebagai pihak yang menetukan regulasi dan pengawasan terhadap pendidikan secara berimbang. Dengan itu semua, barulah kita dapat mengenali permasalahan-permasalahan mendasar berkaitan dengan calistung dengan cara yang lebih baik, serta 
menemukan penyelesaian dengan cara yang lebih proporsional. Dengan cara itu pula kita dapat melihat secara utuh, apakah model pembelajaran Calistung yang marak terjadi di TK/ RA dan penerapan ujian masuk Calistung SD/ MI akhir-akhir ini, dikategorikan sebagai pembelajaran atau justru penyalahgunaan?

\section{B. LANDASAN TEORI}

\section{Pendidikan Anak Usia Dini (TK/RA)}

Belajar merupakan perubahan tingkah laku atau penampilan, dengan serangkaian kegiatan misalnya membaca, mengamati, mendengarkan, meniru dan lain sebagainya. Juga belajar itu akan lebih baik, kalau subyek belajar itu mengalami atau melakukannya, sehingga tidak bersifat verbalistik. Selanjutnya menurut Slamato yang dikutip Tohirin menyatakan bahwa belajar merupakan suatu usaha yang dilakukan individu untuk memperolah suatu

Belajar juga tak terkecuali pada anak anak usia, berdasarkan konsep dasar pendidikan anak usia dini bahwa tonggak sejarah dunia pendidikan anak usia dini dimulai pada tahun 2000 di saat para Menteri Pendidiakan dari 179 negara berkumpul di kota Senegal Negara Dakar di benua Afrika. Di Indonesia termasuk salah satu negara yang membuat komitmen tersebut maka pada bulan Agustus 2001 dibukalah Direktorat Pendidikan Anak Usia Dini (PAUD) di bawah naungan Direktorat Jenderal Pendidikan Luar Sekolah dan Pemuda (Dirjen PLSP),

Departemen Pendidikan Nasional (Depdiknas). Tugas Direktorat PAUD adalah melaksanakan komitmen pertama yaitu memperluas dan memperbaiki keseluruhan perawatan dan pendidikan anak usia dini, terutama bagi anak-anak yang sangat rawan dan kurang beruntung untuk jalur pendidikan nonformal yang berusia lahir sampai dengan usia 6 tahun dan sebagai prioritas anak usia lahir sampai dengan usia 4 tahun. (Widarmi D Wijana. 2014: ix)

Demikian pula dengan masyarakat, sangat penting bagi masyarakat untuk pengetahuan proses pendidikan anak usia dini. Karena seorang anak dapat berkembang secara optimal bergantung dari faktor bawaan (potensi, bakat dan minat) dan juga faktor lingkungan (alam, masyarakat, dan budaya).Oleh karena itu masyarakat juga perlu mendapat perhatian untuk ditngkatkan pemahaman dan pengetahuannya tentang PAUD. 
Pentingnya pendidikan anau usia dini dikemukakan oleh Teyler bahwa pada saat lahir otak manusia berisi sekitar 100 miliar hingga 200 miliar sel saraf. Setiap sel saraf siap berkembang sampai taraf tertinggi dari kapasitas manusia jika menfapat stimulus yang sesuai dari lingkungan.Berdasarkan keterangan Teyler ini, maka inti pada pembelajaran PAUD adalah pemberian stimulus secara tepat, bukan pelejaran mengenai berbagai teori seperti di SD maupun sejenisnya. Inilah sebabnya mengapa Taman Kanak-Kanak (TK) lebih banyak bermain, bernyanyi dan bercerita dari pada pelajaran menghitung dan menulis. Sebab, bermain, bernyanyi dan bercerita merupakan stimulus yang lebih dari pada belajar berhitung dan menulis bagi anak usia dini. (Suyadi:9)

Kemudian mengenai tujuan pendidikan anak usia dini menurut Imam Musbikin yaitu sebagai berikut:

a. Memberikan pengasuhan dan pembimbingan yang memungkinkan anak usia dini tumbuh dan berkembang sesuai dengan usia dan potensinya.

b. Mengidentifikasikan penyimpangan yang mungkin terjadi, sehingga jika terjadi penyimpangan dapat dilakukan intervensi dini.

c. Menyediakan pengalaman yang beraneka ragam dan menghasilkan bagi anak usia dini, yang memungkinkan mereka mengembangkan potensi dalam berbagai bidang, sehingga siap untuk mengikuti pendidikan pada jenjang sekolah dasar (SD).

d. Membangun landasan bagi berkembangnya potensoi peserta didik agar menjadi manusia yang beriman dan bertaqwa kepada Tuhan Yang Maha Esa, berakhlak mulia, sehat, berilmu, cakap, kritis, kreatif, inovatif, mandiri, percaya diri menjadi warga Negara yang demokratis dan bertanggung jawab.

e. Mengembangkan potensi kecerdasan spiritual, intelektual, emosional, dan social peserta didik pada masa emas pertumbuhannya dalam lingkungan bermain yang edukatif dan menyenangkan.(Suyadi:47)

\section{Pandangan Belajar Anak Sekolah Dasar}

Seorang Psikolog Swiss yang bernama Jean Piaget (1896-1980) menyatakan bahwa anak akan membangun dunia kognitif mereka sendiri karena anak mampu mengolah informasi yang diterima untuk mengembangkan gagasan baru, tidak hanya sekedar menerima informasi dari lingkungan. Siswa SD dapat 
diklasifikasikan sesuai perkembangan kognisi menurut Piaget masuk dalam tahap operasional konkret (usia 7-11 tahun). Anak-anak mulai mampu berpikir logis untuk menggantikan cara berpikir sebelumnya yang masih bersifat intuitifprimitif, namun membutuhkan contoh-contoh konkret. Implikasi dari teori Piaget tersebut menunjukkan bahwa pembelajaran di SD harus menggunakan pendekatan melalui kegiatan yang nyata atau konkret. (Suyadi:166)

Dengan pemaparan diatas dapatlah diambil kesimpulan bahwa pembelajaran pada anak-anak SD yang mengalami langsung apa yang dipelajarinya dengan mengaktifkan lebih banyak indra dari pada hanya mendengarkan orang,guru menjelaskan.Masa Usia Sekolah Dasar disebut juga masa intelektual, atau masa keserasian bersekolah pada umur 6-7 tahun anak dianggap sudah matang untuk memasuki sekolah. Masa Usia Sekolah Dasar terbagi dua, yaitu : (a) masa kelas-kelas rendah dan (b) masa kelas tinggi. Adapun Ciri-ciri pada masa kelas-kelas rendah (6/7 - 9/10 tahun) :

a. Adanya korelasi positif yang tinggi antara keadaan jasmani dengan prestasi.

b. Sikap tunduk kepada peraturan-peraturan permainan tradisional.

c. Adanya kecenderungan memuji diri sendiri.

d. Membandingkan dirinya dengan anak yang lain.

e. Apabila tidak dapat menyelesaikan suatu soal, maka soal itu dianggap tidak penting.

f. Pada masa ini (terutama usia $6-8$ tahun) anak menghendaki nilai angka rapor yang baik, tanpa mengingat apakah prestasinya memang pantas diberi nilai baik atau tidak.

Ciri-ciri pada masa kelas-kelas tinggi (9/10-12/13 tahun) :

a. Minat terhadap kehidupan praktis sehari-hari yang konkret.

b. Sangat realistik, rasa ingin tahu dan ingin belajar.

c. Menjelang akhir masa ini telah ada minat kepada hal-hal atau mata pelajaran khusus sebagai mulai menonjolnya bakat-bakat khusus.

d. Sampai usia 11 tahun anak membutuhkan guru atau orang dewasa lainnya untuk menyelesaikan tugas dan memenuhi keinginannya. Selepas usia ini pada umumnya anak menghadapi tugas-tugasnya dengan bebas dan berusaha untuk menyelesaikannya. 
e. Pada masa ini anak memandang nilai (angka rapor) sebagai ukuran tepat mengenai prestasi sekolahnya.

f. Gemar membentuk kelompok sebaya untuk bermain bersama. Dalam permainan itu mereka tidak terikat lagi dengan aturan permainan tradisional (yang sudah ada), mereka membuat peraturan sendiri.

Setiap fase perkembangan anak menunjukkan karakteristik yang berbeda-beda. Demikian pula pada anak usia SD mempunyai karakteristik tersendiri. Menurut Sumantri dan Nana Syaodih karakteristik anak pada usia SD adalah:

a. Senang bermain, karekteristik ini menuntut guru SD untuk melaksanakan kegiatan pendidikan yang bermuatan permainan lebih-lebih untuk kelas rendah. Guru Sd seyogyanya merancang model pembelajaran yang memungkinkan adanya unsur permainan di dalamnya. Penyusunan jadwal pelajaran hendaknya diselang seling antara mata pelajaran serius seperti IPA, Matematika dengan pelajaran yang mengandung unsur permainan seperti Pendidikan Jasmani, Seni Budaya dan Keterampilan.

b. Senang bergerak, Orang dewasa dapat duduk berjam-jam, sedangkan anak SD dapat duduk dengan tenang paling lama sekitar 30 menit. Oleh karena itu guru hendaknya merancang model pembelajaran yang memungkinkan anak berpindah atau bergerak. Menyuruh anak untuk duduk rapi untuk jangka waktu yang lama dirasakan sebagai siksaan.

c. Anak senang bekerja dalam kelompok, dari pergaulannya dengan kelompok sebaya, anak belajar aspek-aspek yang penting dalam proses sosialisasi, contoh belajar memenuhi aturan-aturan kelompok, belajar setia kawan, belajar menerima tanggungjawab, belajar tidak tergantung, belajar bersosialisasi dengan lingkungan. Karakteristik ini membawa implikasi bahwa guru harus merancang model pembelajaran yang memungkinkan anak untuk bekerja atau belajar dalam kelompok.

d. Senang memperagakan atau melakukan sesuatu secara langsung. Ditinjau dari teori perkembangan kognitif, anak sekolah dasar maemasuki tahap operasional konkret. Dari apa yang dipelajari di sekolah, ia belajar menghubungkan konsep-konsep baru dengan konsep lama. Berdasarkan 
pengalamanini, siswa membentuk konsep-konsep tentang angka, ruang, waktu, fungsi-fungsi badan, jenis kelamin, moral, dan sebagainya. Bagi anak SD penjelasan guru tentang materi pelajaran akan lebih dipahami jika anak melaksanakan sendiri. (Mohammad: 154-156).

e. Adapun Tujuan Pembelajaran Di Sekolah Dasar adalah bertujuan memberikan bekal kemampuan dasar baca, tulis hitung, pengetahuan, dan keterampilan dasar yang bermanfaat bagi siswa sesuai dengan tingkat perkembangan serta mempersiapkan mereka untuk mengikuti pendidikan di SMP. Terkait dengan tujuan memberikan bekal kemampuan dasar baca tulis, maka peran pendidikan mampu memberikan bekal pada kemampuan dasar baca tulis mulai pada tahap keterwacanaan (di kelas-kelas awal), sampai pada tercapainya kemahirwacanaan (di kelas-kelas tinggi). (Mohammad: 89-90).

Di sekolah dasar, bagi pembaca pemula yang dimulai pada kelas tiga dan seterusnya dianggap yang paling efektif.Untuk pertukaran gagasan diantara para peserta didik serta sangat efektif dalam memgarahkan dinamika sosial yang terjadi dalam kelompok peserta didik.

\section{METODE PENELITIAN}

Metode yang digunakan dalam penelitian ini adalah penelitian kualitatif yang bertujuan untuk mengumpulkan data-data yang bersifat kualitatif yang berkaitan permasalahan pembelajaran calistung di TK/ RA dan ujian masuk calistung SD/ MI. Data kualitatif yang dimaksud adalah cara pandang, logika, konsep-konsep,nilai-nilai, pengetahuan serta permasalahan-permasalahan dan tantangan yang dimiliki dan dihadapi oleh para guru, baik TK/RA dan SD/ MI. Adapun lokasi penelitian ini akan dilakukan di kota Bandar Lampung. Sebagai setting atau lokasi pesifik yang dipilih beberapa TK/ RA dan SD/ MI baik milik pemerintah ataupun swasta. Penelitian ini bertempat di :

a. Sekolah Dasar Islam Terpadu Permata Bunda 3 Sukabumi Bandar lampung

b. Madrasah Ibtidaiyah Negeri 5 Sukarame Bandar Lampung.

c. Sekolah Dasar Negeri 1 Langkapura Bandar Lampung

d. Sekolah Dasar Negeri 1 Sukarame Bandar Lampung

e. TK An-Nur Kemiling Permai Bandar Lampung 
f. RA Ar-Raudah Kaliawi Bandar Lampung

g. Taman Kanak-kanak Kartika Jaya III - 31 Bandar Lampung

Subyek dalam penelitian ini adalah guru-guru, kepala sekolah dan staf yang ada di TK/ RA dan SD/ MI. Subyek lainnya adalah pihak yang terkait di dinas pendidikan dan kebudayaan kota Bandar Lampung serta orangtua siswa TK/ RA maupun SD/ MI. Adapun teknik pengumpulan data dengan metode observasi, metode Interview dokumentasi. Teknik analisa data, melalui reduksi data, display data, dan verifikasi data.

\section{HASIL DAN PEMBAHASAN}

\section{Proses Pembelajaran Calistung Pada PAUD (TK/RA)}

a. Calistng pada TK An-Nur Kemiling Bandar Lampung, Taman kanak-kanak Kartika Jaya II-31 Bandar Lampung

Hasil observasi dan wawancara baik dengan para guru dan orang tua murid di kedua TK An-Nur Kemiling Bandar Lampung, Taman kanak-kanak Kartika Jaya II-31 Bandar Lampung,diambil kesimpulan bahwa: (Erma Yuni Wati Guru TK An-Nur Kemiling: 2017). Kegelisahan orang tua murid ditanggapi oleh para guru TK An-Nur Kemiling dengan cara memberikan pembelajaran calistung murni. Hal ini terjadi berdasarkan hasil pengamatan peneliti meninjau proses pembelajaran yang berlangsung. Adapun pelaksanaan proses pembelajaran yang dimaksud adalah setelah jam istirahat (09.00-09.20) peserta didik atas perintah guru untuk maju kedapan kelas satu persatu dan disuruh menulis huruf, dan bilangan angka dipapan tulis, sedangkan guru hanya mendektekan. Dari pengamatan tersebut jelas sekali bahwa praktik-praktik pembelajaran calistung murni sudah diberikan dikelas B pada TK An-Nur kemiling Bandar lampung.

Hasil pengamatan dan wawancaralebih lanjut mengindikasikan bahwa sebagian besar dari orangtua murid masih belum mengerti akan arti pendidikan di Taman Kanak-kanak, di mana anak-anak belajar sambil bermain atau bermain sambil belajar. Ini artinya hakikat pendidikan pra-sekolah masih belum dipahami benar oleh mereka selaku guru utama dalam keluarga, bahwa pembelajaran pada jenjang PAUD (TK/RA) adalah pembelajaran yang mengedepankan aspek motorik kasar dan motorik halus. 
Beberapa kemampuan motorik kasar adalah gerakan tubuh yang menggunakan otot-otot besar, sebagain besar atau seluruh anggota tubuh yang dipengaruhi oleh usia, berat badan dan perkembangan anak secara fisik. Kecerdasan motoric halus anak sangat penting karena berpengaruh pada segi pembelajaran lainnya. Pada usia 5-6 tahun koordinasi gerakan motorik halus berkembang pesat. Menurut Mayke (2007) bahwa motoric halus penting karena ini nantinya akan dibuthkan anak dari segi akademis. Pada masa ini anak telah mampu mengkoordinasikan gerakan visual motorik.Anak dalam kelompok ini lebih menyukai permainan yang tidak banyak melibatkan motorik kasar. Mereka lebih menyukai permainan yang menggunakan kemampuan berfikir seperti permainan puzzle, balok, bongkar pasang mobil, bermain games. Aspek pengembangan fisik untuk motoric halus meliputi: mencontoh bentuk, menjiplak angka dan bentuk-bentuk lain, menjahir sederhana, memasukkan surat ke dalam amplop, membentuk dengan plastisin, memasukkan benang kedalam jarum, menggunting, membetuk berbagai objek dengan tanah liat, menganyam, menggambar sesuai dengan gagasannya, melakukan berbagai eksplorasi dengan berbagai media, menggunakan alat tulis dengan benar, menggunting sesuai dengan pola, menempel gambar dengan tepat, mengeskspresikan diri melalui gerakan menggambar secara detail. (Diara Zha: 2012)

Berdasarkan teori diatas anak harus diberikan intervensi-intervensi yang tepat agar otak anak bisa berkembang dengan optimal.Intervensi yang diberikan bisa dalam bentuk stimulasi-stimulasi.Stimulasi yang diberikan harus merangsang 4 aspek kemampuan dasar yaitu kemampuan gerak kasar, gerak halus, kemampuan berbicara dan bahasa, dan kemampuan bersosialisasi.

b. Calistung Pada Raudhatul Athfal Ar-Raudhah Kaliawi Bandar Lampung Berdasarkan hasil pengamatan Ar-Raudhah PlayGroup and Kindergaerten khususnya para ibu yang anaknya sudah di kelas B di Ar-Raudah para orangtua bereaksi keras merespon keterlambatan anaknya dalam membaca. Bagi mereka, keterampilan anak membaca bisa jadi merupakan sebuah "prestasi" membanggakan yang layak diceritakan kepada kerabat dan relasi termasuk kebanggaan tersendiri bagi para orang tua terutama ibu-ibu orang tua murid. Bahkan para orangtua mempersepsikan, lancar baca adalah jaminan paling oke 
untuk dapat melanjutkan kejenjang sekolah dasar. Sehingga dampaknya banyak orangtua lalu beramai-ramai menempuh "jalan pintas" yakni memanggil guru les privat mengajari anaknya supaya cepat bisa baca.Kalau perlu, "Anakku harus lebih lancar daripada teman-teman di kelasnya”. (Umi Eni Guru Raudatul Athfal Ar-Raudhah Kaliawi:2017)

Kepala Ar-Raudah PlayGroup dan Kindergarten yang bernama Ibu Suci Indah menanggapi pertanyaan dan kegelisahan orangtua tersebut dengan berkomnetar jika ada Ujian calistung yang diterapkan ketika akan memasuki Sekolah dasar walaupun ujian bukan merupakan syarat mutlak disekolah dasar tetapi tetap saja peristiwa tersebut tidak mengenakkan (traumatik). yang dialami anak yang akan berpengaruh terhadap keseimbangan kematangan emosi. Dengan alasan bahwa sejak usia 2 bulan sudah berkembang perasaan stress, kepuasan, sedih, dan gembira. Pemaksaan terhadap anak untuk mampu membaca, menulis dan berhitung merupakan peristiwa yang tidak mengenakkan (traumatic) yang dialami anak yang akan berpengaruh terhadap keseimbangan kematangan emosi.

c. Bentuk-Bentuk Pembelajaran Calistung di PAUD ( TK/RA)

Keinginan orangtua supaya anaknya bisa baca dalam waktu singkat sering dituruti oleh para guru dengan menempuh jalan pintas. Guru lalu memaksa diri dan muridnya belajar membaca dengan menghafalkan lambang bunyi. Murid "dipaksa" melafalkan rangkaian huruf sebagai kata, tetapi tanpa makna yang dipahami dan menjadi perhatian anak yang sedang belajar.

Berdasarkan pengamatan peneliti di TK kartika Jaya II-31 Bandar Lampung dalam proses pengenalan huruf dan angka bilangan untuk kelas A ( 4 -5 tahun) diperkenalkan angka 1-5. Adapun untuk kelas B (5-6 tahun) diperkenalkan angka bilangan 1-10. Adapun proses pembelajaran terlebih untuk kelas A guru dalam memperkenalkan membaca dan mengenalkan angka bilangan dengan cara membacakan buku cerita sambil memperlihatkan gambar dan tulisan di buku/majalah yang sedang dibacakan, menempelkan gambar-gambar yang berhubungan dengan huruf atau tulisan. Sedangkan untuk kelas B sebagai persiapan untuk memasuki sekolah dasar lebih banyak mengajarkan calistung dengan pembelajaran murni tanpa diselingi dengan kegiatan bermain guru mengajar membaca dengan metode: ba-bi-bu-be-bo, ca-ci cu-ce-co,da-di-de-do 
murid disuruh untuk menirukan gurunya melafalkan huruf sampai beberapa kali untuk kemudian murid disuruh untuk maju kedepan kelas satu persatu diperintahkan untuk menulis huruf sampai selesai dan dilanjutan dengan membaca huruf yang telah ditulis.

Dilanjutkan dengan wawancara dengan guru Tk yang bernama Ibu Tuti bentuk-bentuk pembelajaran calistung murni jelas-jelas diberikan pada saat ada jam tambahan untuk kelas B sebagai persiapan melanjutkan kesekolah dasar. Pembelajaran jam tambahan ini dilakukan karena usulan orang tua yang menginginkan anak-anaknya untuk terampil dalam calistung lebih parah lagi, banyak orangtua yang tak acuh akan tahap kepekaan anak dalam membaca dan cara yang benar dalam mengajarkan membaca yang mengembangkan kecerdasan. (Tuti, Guru TK Kartika Jaya II-31: 2017)

Anak pada usia lahir sampai dengan usia memasuki pendidikan dasar ( lahir-6 tahun) merupakan "masa emas" sekaligus "masa kritis" dalam tahapan kehidupan manusia yang akan menentukan perkembangan selanjutnya. Dikatakan "masa emas" karena pada masa ini adalah saat yang paling baik untuk mengoptimalkan seluruh aspek-aspek perkembangan anak. Dikatakan "masa kritis" karena pada masa usia tersebut anak-anak masih sangat rentan sehingga apabila intervensi atau penanganan yang diberikan atau dilakukan terhadap anak didik tidak tepat maka hal tersebut akan dapat merugikan anak itu sendiri dan akan berakibat kurang baik bagi kehidupannya dimasa yang akan datang. (Widarmi D Wijaya. 2014: x)

Proses belajar menuju kemampuan baca tulis pada anak TK sebaiknya tidak dilakukan dengan pendekatan formal, seperti layaknya anak-anak SD. Karena hal ini dikhawatirkan akan membuat anak merasa tertekan dan jenuh, mengingat kemampuan anak untuk bisa berkonsentrasi pada satu topik bahasan biasanya masih sangat terbatas dan secara umum anak masih berada dalam dunia bermain. Apalagi bila dalam memberi pelajaran tersebut dilakukan dengan kekerasan, misalnya disertai dengan bentakan-bentakan, hinaan atau ejekan manakala anak belum mampu mengikuti pelajaran baca tulis yang diberikan, maka bukan tidak mungkin anak akan tumbuh menjadi anak rendah diri, yang 
justru hal ini akan menghambat perkembangan kemampuannya secara optimal kelak kemudian hari.

\section{Calistung Ujian Masuk Sekolah Dasar}

Hasil wawancara pada Kepala MIN 5 Sukarame Ibu Hj. Salmah , memperjelas bahwa masih memperaktikkan atau mengadakan test masuk sekolah dengan cara menjawab pertanyaan. Peserta juga dipersilahkan menggunakan jari untuk berhitung”. (Salma,Kepala MIN 5 Sukarame. 2017)

Bagi sekolah yang berbasis Islam (MIN 5 Sukarame) selain tes diatas, umumnya ditambahkan dengan ujian terkait keislaman. Adapun ujian yang biasa dilakukan adalah: ujian kemampuan membaca huruf hijaiyah. Yang sering menjadi bahan ujian pada tahap ini umumnya adalah membaca iqra jilid satu. Dimana akan dibuka secara acak buku iqra dan kemudian guru menunjuk huruf dan murid diminta menyebutkan huruf yang ditunjukkan.

Pada sektor hafalan, umumnya murid diminta menghafal doa yang pendek dan sering dipakai, seperti doa mau tidur, doa bangun tidur, doa mau makan. Dilanjutkan dengan menghapal surat-surat pendek semisal An-nas, Al falaq, Al Fatihah. ( Lidya Kastriadana, Guru Kelas 1 MIN 5 Sukarame. 2017)

Dari hasil wawancara dengan para orang tua murid dapat diambil kesimpulan bahwa, para orang tua murid sepertinya paham benar ketika ingin menyekolahkan anaknya ke MIN 5 Sukarame Bandar Lampung sudah mengetahui akan prosedur agar anaknya bisa diterima disekolah tersebut. selain memenuhi persyaratan administrasi yaitu umur tidak boleh kurang dari 6 tahun juga dituntut untuk mampu calistung sederhana.

Data yang selanjutnya adalah peneliti mengunjungi SDN 2 Sumberejo Kemiling Bandar Lampung, dan berhasil melakukan wawancara dengan guru kelas 6 yang bernama Ibu Ana Maria. Beliau memaparkan bahwa untuk bisa masuk sekolah SDN 2 Kemiling ini calon murid di tes dengan materi sebagai berikut:

"Mengenal huruf, dimana tercetak huruf a-z dalam sebuah kotak dan anak ditugaskan menulis kembali huruf tersebut pada kotak kosong dibawahnya.Mengenal angka, hampir sama dengan mengenal huruf, dimana 
tercetak angka 1-10 dan anak ditugaskan menulis kembali angka tersebut pada kotak kosong dibawanya. Membaca, dimana tercetak dua kata sampai tiga kata dalam tulisan yang besar dan tercetak tebal ebagai contoh. Mama papa, baju, bata." (Ana Maria, Guru Kelas 6 SDN 2 Kemiling: 2017)

Dalam pelaksanaan soal ujian masuk SD lebih bersifat rileks, santai dan sekali-kali guru mengajak murid untuk bergurau . Hal ini dilakukan agar calon siswa tidakterkesan seperti sedang ujian sehingga calon siswa tidak stres atau takut ketika menghadapi ujian.

Wawancara dilanjutkan dengan Guru Kelas 1 SDN 2 Kemiling Bandar Lampung Ibu Sri Winarti sebagai berikut:

“Apakah sekolah ini mengadakan tes membaca, menulis dan berhitung untuk masuk sekolah dasar di SDN 2 kemiling ini? Beliau menjawab bahwa tidak ada tes disekolah ini kecuali kami meminta persyaratan administrasi yang harus dipenuhi oleh orang tua yang ingin menyekolahkan anaknya di SDN 2 Kemiling ini. Adapun syaratnya adalah yang terpenting jika anak sudah berumur minimal 6 tahun, berdomisili dilingkungan sekolah"adapun jika kami menanyakan beberapa hal seperti nama calon siswa, nama orang tua, nama kakak adik calon siswa itu hanya karena ingin agar tidak kecolongan dengan calon siswa yangsemestinya bersekolah di SLB . (Sri Winarti, Guru kelas 1 SDN 2 Kemiling: 2017)

Tetapi ketika peneliti melakukan wawancara dengan salah satu wali murid sebut saja Lisfatmawati mengungkapkan bahwa ketika anaknya mendaftar untuk masuk SDN 2 Kemiling, panitia penerimaan murid baru mengadakan semacam tes calistung, tetapi yang diujikan hanyalah tes membaca saja. Dalam pelaksanaan soal ujian masuk SD lebih bersifat rileks, santai dan sekali-kali guru mengajak murid untuk bergurau. Hal ini dilakukan agar terkesan tidak seperti sedang ujian sehingga anak tidak stres atau takut ketika menghadapi ujian. Dimana guru atau penguji aktif dalam bertanya kepada calon murid. Umumnya dalam ujian ini orang tua atau wali murid mendampingi ketika ujian masuk Sekolah Dasar berlangsung.

Berdasarkan survei disekolah SDN2 Kemiling Bandar Lampung peneliti menyimpulkan bahwa ada ketidaksingkronan antara guru dengan guru, kenyataan dilapangan bahwa pada hakekatnya memang ada ujian masuk sekolah tetapi sifatnya hanya untuk mengukur kemampuan calon siswa bukan untuk menentukan lulus tidaknya. Pengambilan data dilanjutkan ke SDIT Permata Bunda 3 
Sukabumi Bandar Lampung, berdasarkan hasil wawancara dengan kepala sekolah SDIT Permata Bunda 3 Sukabumi Bandar lampung Bapak Septo Wahyudi, mengatakan:

"Bahwa sekolahnya tidak mengadakan tes calistung untuk masuk SD, sementara bentuk tes yang dilakukan pihak sekolah lebih kepada menggali informasi dari orang tua untuk mengetahui potensi anak, minat dan bakat anak-anak mereka. Jaringan sekolah Islam terpadu (JSIT) adalah contoh konkritnya, saat mendaftar orang tua dan calon siswa diarahkan untuk mengikuti tes observasi dalam bentuk intervieu dengan pihak sekolah. Pertanyaannya sendiri lebih pada kebiasaan anak di rumah, pengenalan lingkungan, potensi, dan bakat anak serta hubungan anak dengan orang tua.Jadi sifatnya lebih kepada kesiapan anak untuk bersekolah bukan kemampuan akademik anak". (Septo Wahyudi, Kepala Sekolah Islam Terpadu (SDIT): 2017)

Survei dilanjutkan wawancara dengan orang tua murid Ibu Nurul yang menyatakan bahwa di SDIT Permata Bunda 3 ini tidak ada tes membaca, menulis, dan berhitung yang ditanya adalah bagaimana keseharian anak di rumah, bagaimana bersosialisasi dengan lingkungan di tempat tinggal, semua pertanyaan lebih kepada kesiapan dari aspek psikologi anak. (Orang Tua N, Wawancara: 2017)

Dari sini bisa dijelaskan bahwa observasi tes bukanlah sarana untuk memutuskan anak lulus atau tidak lulus sehingga tidak dapat dikategorikan melanggar program wajib belajar 9 tahun dan otomatis tidak pula bertentangan dengan pasal 69 dari PP 17 tahun 2010. Pendapat ini diperkuat lagi oleh ketua Dewan Pembina Komnas Perlindungan Anak (PA), Seto Mulyadi, yang mengatakan bahwa ujian masuk pada tingkat sekolah dasar orientasinya mestilah menjurus pada kesiapan anak untuk bersekolah, baik terkait dengan kemandirian, rasa percaya diri, serta ketergantungan terhadap orang tua. (https://m.antaranews.com: 2017)

Artinya ujian masuk pada sekolah dasar tetap boleh dilakukan sepanjang tidak berorientasi pada lulus atau tidak lulus. Akan tetapi syarat adminstrasi harus tetap diberlakukan dengan ketentuan usia masuk sekolah tidak boleh kurang dari 6 tahun yang dapat dibuktikan dengan akte kelahiran. Pertimbangan berikutnya adalah, yakni jarak tempat tinggal calon peserta didik yang paking dekat dengan 
satuan pendidikan dibuktikan dengan kartu keluarga.Selain itu biasanya mempertimbangkan urutan pendaftaran.Berbeda lagi dengan SDN 1 Sukarame Bandar Lampung dan SDN 1 Langkapura Bandar Lampung yang tidak melakukan tes kognitif (calistung) pada saat penerimaan siswa baru sekolah dasar. Berdasarkan wawancara dengan guru kelas 1 SDN 1 Sukarame Ibu Inawati memaparkan bahwa untuk masuk SD seorang siswa hanya perlu cukup umur dan domisilinya dekat dengan sekolah. Selain itu untuk masuk SD tidak mensyaratkan ijazah TK. Usia untuk masuk SD minimal 6 tahun. Ada beberapa pertanyaan yang selalu guru ajukan terhadap peserta ujian masuk SD untuk menyebutkan namanya, nama ibu, dan nama bapak. Hal ini dilakukan pihak sekolah karena menghindari terjadinya "kecolongan" terhadap murid-murid yang hiper aktif, autis, karena memang letak sekolah SDN 1 Langkapura dengan Sekolah Luar Biasa (SLB) hanya berjarak lenih kurang 500 M saja. (Inawati, Guru Kelas 1 SDN 1 Sukarame: 2017)

Tetapi berdasarkan hasil wawancara dengan kepala TU SDN 1 Sukarame sebut saja Ibu Sum, mengungkapkan bahwa untuk bisa masuk sekolah SDN 1 Sukarame memang diberlakukan tes ujian masuk tetapi bentuk tes ujian masuk SDN 1 Sukarame untuk 3 tahun belakangan ini tidak sesulit seperti dulu. (Ibu Sum, Kepala TU SDN 1 Sukarame: 2017)

Ada ketidaksingkronan data lapangan yang didapat dalam hal ini keterangan (wawancara) dari guru Ibu Inawati dengan Kepala TU SDN 1 Sukarame Bandar lampung. Menurut analisa peneliti ini dikarenakan pihak sekolah sangat hati-hati dalam penerimaan siswa dikarenakan Dinas Pendidikan akan memberikan sanksi kepada SD yang menerapkan model seleksi dalam PPDB ( penerimaan peserta didik baru). Permendikbud Nomor 17 Tahun 2017 tentang PPDB bertujuan untuk menghindari adanya sekolah yang menolak siswa dengan alasan apapun. (Yasin Habibi: 2017)

Untuk mendapatkan sinkronisasi data dilapangan maka peneliti mendatangi Dinas Pendidikan dan kebudayaan Kota Bandar lampung, berdasarkan wawancara dengan Ibu Endang Trimurti selaku Kasub PAUD mengatakan bahwa"

"Kami pihak Dinas Pendidikan selalu berupaya dengan berbagai cara untuk mengingatkan guru-guru TK/RA untuk tidak menerapkan calistung 
disekolah, karena TK/RA bukan lembaga prasekolah tetapi masa bermain anak. Adapun cara kami dengan memberikan surat edaran yang didapat dari pusat ke dinas Kota untuk kemudian dari dinas kota diturunkan kekecamatan, dari kecamatan baru diturunkan kesekolah-sekolah. Ataupun dengan melakukan himbauan dengan cara kami datang ke TK/RA, ataupun pengelola TK/RA dan guru-guru yang datang ke Dinas Kami selalu menyisipi himbauan agar dalam memberikan pembelajaran di TK/RA hindari pemberian calistung. Sebenarnya TK/RA mereka sudah mengetahui akan larangan pemberian calistung kepada anak-anak TK/RA tetapi hal ini dilakukan karena desakan atas orang tua yang senantiasa memaksa agar anak-anak mereka diajarkan untuk bisa membaca, menulis dan berhitung sebagai persiapan untuk masuk kesekolah dasar. (Endang Trimurti, Kepala Sub Bagian PAUD Dinas Pendidikan dan Kebudayaan Kota Bandar Lampung: 2017)

Berbagai penelitian dan pendapat yang mendukung bahwa anak usia dibawah 7 tahun tidak dianjurkan untuk belajar calistung. Alasan tersebut merujuk kepada penelitian seorang ahli psikolog perkembangan anak dari Swiss Jean Piaget, karena pada masa itu anak-anak belum dapat berpikir operasional konkret sehingga ditakutkan pelajaran tersebut akan membebani anak-anak yang belum mampu untuk berpikir secara terstruktur. (ww.bimba-aiueo.com. 2013) Sementara itu kegiatan calistung sendiri didefinisikan sebagai kegiatan yang memerlukan cara berpikir tersruktur, sehingga tidak sesuai bila diajarkan pada anak usia di bawah 7 tahun. Pieget mengkhawatirkan otak anak-anak tersebut menjadi terbebani dan tujuan awal mencerdaskan anak menjadi dilema karena justru anak-anak menjadi tidak bahagia dan tidak bisa menikmati kehidupan mereka.

Berkaitan dengan mutu, masih sering terjadi kesalahan persepsi dari pihak orang tua dan masyarakat umum. Mereka beranggapan bahwa pendidikan anak usia dini yang bermutu adalah yang tidak terlalu banyak bermain, sehingga lulusannya lancar dalam membaca, menulis dan berhitung. Hal ini berdampak terjadinya pemaksaan proses belajar yang merugikan kepentingan anak. Konsep pendidikan anak usia dini yang menekankan proses bermain sambil belajar atau belajar sambil bermain, berubah menjadi belajar-belajar. Banyak para pendidik mencari jalan pintas dalam mengajarkan membaca menulis dan berhitung permulaan kepada anak dengan mengabaikan tahap tumbuh kembang dan irama belajar anak. 
Untuk mengetahui sejauhmana pelaksanaan Permen 17 tahun 2010 Pasal 69 Ayat 5, yakni: "penerimaan peserta didik kelas 1 (satu ) SD/MI atau bentuk lain yang sederajat tidak didasarkan pada hasil tes kemampuan membaca, menulis, dan berhitung, atau bentuk tes lain". Peneliti melakukan wawancara kepada Kasi SD di Dinas Pendidikan dan Kebudayaan Kota Bandar Lampung yang bernama Ibu Mega mengatakan bahwa:

"Dalam pelaksanaan penerimaan murid baru pada sekolah dasar sudah ada ketetapan yang merujuk pada Pasal 70 Ayat 1-5 yakni (1) dalam hal jumlah calon peserta didik melebihi daya tampung satuan pendidikan, maka pemilihan peserta didik pada SD/MI berdasarkan pada usia calon peserta didik dengan prioritas dari yang paling tua, (2) jika usia calon peerta didik sebagaimana dimaksud pada ayat 1 sama, maka penentuan peserta didik didasarkan pada jarak tempat tinggal calon peserta didik yang paling dekat dengan satuan pendidikan, (3) jika usia dan ataupun jarak tempat tinggal calon peserta didik dengan satuan pendidikan sebagaimana dimaksud pada ayat 1 dan ayat 2 sama, maka peserta didik yang mendaftar lebih awal diprioritaskan

Menurut kepala senksi pendidikan dasar ibu mega bahwa jika ada sekolah dasar yang menerapkan ujian masuk calistung sekolah dasar di Bandar lampung maka kami menerapkan aturan sanksi dari mulai teguran lisan, tertulis dan pemberlakuan sanksi adapun pemberlakuan sanksi mulai dari indisipliner, penundaan kenaikan gaji berkala, penundaan kenaikan Pangkat, dan terakhir pemberentihan dengan tidak hormat. Sampai saat ini memang ada sekolah yang menerapkan ujian masuk calistung sekolah dasar dan kami melakukan sanksi teguran lisan dan tertulis. (Mega, Kepala Seksi Pendidikan Dasar Dinas Pendidikan Dan Kebudayaan Kota Bandar Lampung: 2017)

\section{E. KESIMPULAN}

Pembelajaran calistung pada anak usia dini (4-6 tahun ) tidak harus diberikan karena mengingat bahwa mengharuskan anak TK bisa membaca dan menulis, berarti memaksakan anak untuk memiliki kemampuan yang seharusnya baru diajarkan di SD. Hal ini membuat aktivitas bermain anak yang seyogyanya dominan untuk usia mereka, menjadi berkurang atau bahkan terabaikan, sehingga 
dikhawatirkan akan menghambat perkembangan potensi-potensi kemampuan anak secara optimal kelak kemudian hari.

Cara atau bentuk pembelajaran calistung pada anak usia dini mengacu pada karakteristik umum anak TK, dimana aktivitas bermain menjadi aktivitas dominan mereka, maka perlu diingat bahwa dalam memberikan pelajaran baca tulis pada anak TK hendaknya dilakukan dengan pendekatan yang menyenangkan anak dan tidak memaksa anak. Pendekatan informal dimana pelajaran disampaikan dalam koridor bermain tampaknya menjadi sesuatu yang cocok untuk diterapkan pada pengajaran baca tulis anak-anak TK/RA. Pendekatan informal yang dapat dilakukan, misalnya membacakan buku cerita sambil memperlihatkan gambar dan tulisan di buku/majalah yang sedang dibacakan, menempelkan gambar-gambar yang berhubungan dengan huruf atau tulisan pada ruang bermain atau kamar tidur anak, mecoba meniru bentuk lingkaran/garis atau huruf tertentu, mengajak anak menonton film yang bersifat mendidik sekaligus menghibur sehubungan dengan pelajaran baca tulis, bermain tebak-tebakan huruf, menelusuri bentuk huruf dengan jari, dan sebagainya.

\section{F. DAFTAR PUSTAKA}

Ahimsa-Putra, Heddy Shri. 1985. "Etnosains dan Etnometodologi: Sebuah Perbandingan" dalamJurnal Masyarakat Indonesia. Jilid XII Nomor 2. LIPI

1997. "Majalah PRISMA, No. 1 Tahun XXVI Januari, 1997.Sungai dan Air Ciliwung, Sebuah Kajian Etnoekologi" dalam Ahimsa-Putra, Heddy Shri.“Sungai dan Air Ciliwung, Sebuah Kajian Etnoekologi”.PRISMA, No. 1 Tahun XXVI Januari.

2012.’Budaya Bangsa- Peran untuk Jati Diri dan Integrasi” Makalah Seminar Nasional Peran Sejarah dan Budaya dalam Pembinaan Jatidiri Bangsa. Fakultas Ilmu Sosial - Universitas Negeri Yogyakarta Yogyakarta, 4 Juli

Cassirer, Ernst. 1944. An Essay of Man.An Introduction to Philosophy of Human Culture. Doubleday and Company. INC, Garden City, New York.

Denzin, N.K. 2006. "Analytical Autoethnography, or Deja Vu all Over Again” dalam Journal of Contemporary Ethnography.35, 4. 
Hanifah, Nanang, dan Cucu Suhana. Konsep Strategi Pembelajaran. PT. Refika Aditama. Bandung.

Heruman. 2013. Model Pembelajaran Matematika di sekolah Dasar. PT. Remaja Rosdakarya. Bandung.

Hibana S. Rahman. 2002. Konsep Dasar Pendidikan Anak Usia Dini. PGTKI Press. Yogyakarta.

Lexy ,Moloeng. 2004. Metode Penelitian Kualitatif. Rosdakarya. Bandung.

Imam Musbikin. 2010. Buku Pintar PAUD. Laksana. Yogyakarta.

Jalal, Fasli\& Sardjunani. 2006. Rangkuman Laporan Penelitian: "Pendidikan Untuk Semua. Keaksaraan Untuk Kehidupan”.

Maryatun, Ika Budi. Tanpa tahun. "Calistung untuk Paud" dalam makalah Program Pelatihan Tenaga Pendidik PAUD Kecamatan Tempel, Yogyakarta. Dinas Pendidikan dan Kebudyaaan Sleman.

Mansur. 2005. Pendidikan Anak Usia Dini Dalam Islam. Pustaka Belajar. Yogyakarta.

Malinowski, B. 1961. Argonauts of the Western Pacific. E.P. Dutton. New York.

Nasution. 2003. Metode Penelitian Naturalistik Kualitatif. Tarsito. Bandung.

Syaodih ,Ernawulan dan Mubiar Agustin. 2014. Bimbingan Konseling Untuk Anak Usia Dini. Penerbit Universitas Terbuka

Sumantri, Mohamad. 2015. Strategi Pembelajaran Teori dan Praktik Di Tingkat Pendidikan Dasar. PT. Raja Grafindo Persada. Jakarta.

Suyono dan Hariyanto. 2011. Belajar dan Pembelajaran. PT. Remaja Rosdakarya. Bandung.

Soetomo. 1993. Dasar-Dasar Interaksi Belajar Mengajar. Usaha Nasional. Surabaya.

Tohirin. 2011. Psikologi Pembelajaran Pendidikan Agama Islam Berbasis Integrasi dan Kompetensi. PT. Raja Grafindo Persada. Jakarta.

Werner, O dan J. Fenton. 1970. "Method and Theory in Ethnoscience or Ethnoepistemology", dalam Handbook of Method in Cultural Anthropology, R. Naroll dan R. Cohen (eds.). Natural History Press. New York. 
White, Leslie. 1949. "The Symbol: The Origin and the Basis of Human Behavior," dalam The Science of Culture: A Study of Man and Civilization. Far Straus \& Giroux, Inc.

Yusuf L.N, Syamsu, Dkk. 2011. Perkembangan Peserta Didik. PT. Raja Grafindo. Jakarta.

Dyah Ratna Meta Novi. "Calistung Perlu Diajarkan ke Balita, Ini Caranya" Senin ,http://www.republika.co.id/berita/humaira 16 December 2013

Salmah Muslimah. "Tak Dianjurkan Calistung, Begini Cara Belajar Balita Imbauan Kemendikbud". http://news.detik.com/berita/3081422/. Kamis 26 Nov 2015.

"Kak Seto : Calistung Adalah Kompetensi Anak SD, Bukan Anak TK" http://jambi.tribunnews.com/2015/07/30/. Kamis, 30 Juli 2015 22:14

“Masuk SD, Masalah Mengepung dari Tes Calistung Sampai Pungli”05 Jun 2012, 12:04

http://riniraihan.wordpress.com, diakses pada tanggal 23 oktober 2017

http://lenterainsan .com/motoric-halus-sebagai-stimulasi-kemampuan-menulispermulaan-pada-anak-usia-dini-detail-20789.html, diakses pada tanggal 23 oktober 2017

www.bimba-aiueo.com, pro-kontra-mengajarka calistung pada anak usia dini, Artikel Menarik, 19 Juni 2013, Di Akses Pada Tanggal 20 Nopember 2017

Yasin Habibi. Republika. Tanggal 04 Juli 2017, di Akses Tanggal 17 Nopember 2017.

https://m.antaranews.com berita sekolah dilarang terapkan tes calistung masuk SD, Di Akses Tanggal 10 Nopember 2017. 